\title{
Памяти Вячеслава Романовича Исаева
}

$$
\text { (03.01.1940-01.06.2021) }
$$

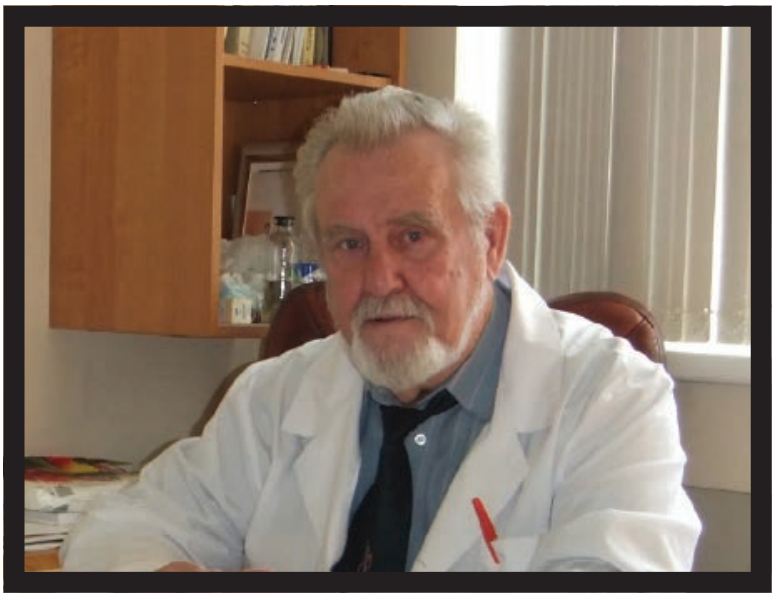

На 82 году жизни скончался замечательный российский врач-хирург - ученик профессора А.М. Аминева, доктор медицинских наук, профессор кафедры и клиники госпитальной хирургии Самарского государственного медицинского университета Вячеслав Романович Исаев.

В.Р. Исаев родился в 1940 году в городе Ульяновск. Детство прошло в тяжелые голодные военные и послевоенные годы. В 1963 г. закончил Куйбышевский медицинский институт им. Д.И. Ульянова. С 3-го курса была выбрана будущая специальность - хирургия, любовь и верность к которой Вячеслав Романович пронес в своем сердце через всю жизнь!

С 1963 по 1965 г. он обучался в клинической ординатуре (спецординатура с углубленным изучением английского языка) на кафедре госпитальной хирургии. В 1965-1966 г. В.Р. Исаев работал ординатором хирургического отделения МСЧ № 5 Куйбышевского металлургического завода имени В.И. Ленина, набираясь опыта в экстренной хирургии. Приходилось выполнять до 20 неотложных операций за сутки!

С 1966 года - младший научный сотрудник научноисследовательской лаборатории по проктологии при Куйбышевском мединституте. В 1969 году избран по конкурсу ассистентом кафедры госпитальной хирургии.

В 1970 году в Донецком медицинском институте защищена кандидатская диссертация на тему «Нарушение обмена белка у больных полипозом толстой кишки».

С 1972 по 1975 годы была заграничная командировка в Африку в Республику Мали в качестве хирурга и преподавателя хирургии.

В 1979 г. В.Р. Исаев избран доцентом кафедры госпитальной хирургии. Параллельно с активной хирургической работой в клинике В.Р. Исаев вел интенсивные исследования по выбору оптимальных методов лечения полипозных синдромов.

В 2001 году Вячеслав Романович успешно защитил докторскую диссертацию на тему «Консервативное и хирургическое лечение полипоза толстой кишки».

С 2001 года до последних дней жизни Вячеслав Романович работал в должности профессора кафедры госпитальной хирургии. Более 50 лет он преподавал госпитальную хирургию студентам в стенах родного университета. Его занятия и лекции были всегда очень интересны, наполнены богатым жизненным опытом, которым профессор щедро делился со студентами и молодыми докторами.

Профессор Исаев В.Р. награжден грамотами Министерства здравоохранения РФ, Министерства здравоохранения Самарской области, СамГМУ, значком «Почетный выпускник СамГМУ». В 2003 году за многочисленные работы в области колопроктологии профессор Исаев был удостоен премии им. А.М. Аминева, которая была вручена ему на Первом Российском съезде колопроктологов. В 2015 году за большие заслуги в развитии отечественного здравоохранения Вячеславу Романовичу Исаеву присвоено почетное звание «Заслуженный работник здравоохранения России».

Большинство колопроктологов Самары и Самарской области прошли обучение на кафедре госпитальной хирургии нашего университета и по праву считают своим учителем профессора В.Р. Исаева. Более 30 лет профессор Исаев В.Р. возглавлял колопроктологическую службу Самарской области, являясь главным внештатным специалистом-колопроктологом Министерства здравоохранения Самарской области.

Профессор Исаев В.Р. - автор более 150 научных работ в области хирургии и колопроктологии, 10 монографий и учебных пособий. Блестящие выступления и доклады профессора В.Р. Исаева на заседаниях Самарского областного научно-практического общества хирургов многократно награждались в номинации «Лучший доклад года».

Хирурги Самарской области, ученики и сотрудники Самарского государственного медицинского университета глубоко скорбят о потере своего коллеги В.Р. Исаева Врача, Ученого, Педагога!

Коллектив ФГБУ «НМИЦ колопроктологии имени А.Н. Рыжих» Минздрава России, сотрудники кафедры и клиники госпитальной хирургии ФГБОУ ВО СамГМУ, члены Ассоциации колопроктологов России и редакция журнала «Колопроктология» выражают глубокое соболезнование родным и близким Исаева Вячеслава Романовича. 